\title{
STUDENTS' VIEWS ON THE UTILIZATION OF KINEMASTER APPLICATIONS FOR PICTURE DESCRIBING TECHNIQUE IN ENGLISH FOR TOURISM SUBJECT
}

\author{
Fuad Abdul Baqi ${ }^{1}$ \\ ${ }^{1}$ Universitas Bina Bangsa \\ fuadbaqi80@gmail.com
}

\begin{abstract}
ABSTRAK
Tujuan dari penelitian ini adalah untuk mengetahui pandangan mahasiswa tentang Pemanfaatan Aplikasi KineMaster dalam Penerapan Teknik Picture Describing Bahasa Inggris untuk Pariwisata. Metode yang digunakan adalah metode deskriptif verifikatif dengan pendekatan ex post facto dan survey. Instrumen yang digunakan adalah angket yang dibagikan kepada mahasiswa Jurusan Bahasa Inggris STKIP La Tansa Mahiro. Hasil penelitian menunjukkan secara umum, sebagian besar responden setuju bahwa Teknik Picture Describing menggunakan aplikasi KineMaster sangat bermanfaat dan relevan untuk digunakan dalam bahasa Inggris Pariwisata. Hal ini dibuktikan dengan hasil 75\% siswa setuju bahwa Teknik Picture Describing menggunakan aplikasi KineMaster cukup relevan dan sesuai untuk diterapkan dalam Bahasa Inggris Pariwisata, 20\% sangat setuju dan 4,2\% tidak setuju.
\end{abstract}

Kata kunci: Pandangan siswa, Kinemaster, Teknik Menggambar Gambar, Bahasa Inggris Pariwisata.

\begin{abstract}
The purpose of this research was to determine students' views on the Utilization of KineMaster Applications in Implementing Picture Describing Technique of English for Tourism. The method used is the descriptive verification method with ex post facto and survey approaches. The instrument used was a questionnaire distributed to students of English Department of STKIP La Tansa Mahiro. The results showed in general, it was found that the most of respondents agree that Picture Describing Technique using KineMaster application is very beneficial and relevant to be used in English for Tourism class. This is evidenced by the results of $75 \%$ of students agree that Picture Describing Technique using KineMaster application is quite relevant and appropriate to be implemented in English for Tourism, 20\% strongly agree and 4,2\% disagree.

Keywords: Students' views, Kinemaster, Picture Describing Technique, English for Tourism.
\end{abstract}


Learning is a process of learning activities that engage participation of teachers and students. Besides teacher and students involvement, learning is also closely related to the curriculum and development of science and technology. Learning in this era requires students to be more active, and teachers also must always be creative in designing learning media so that the learning process runs as planned. Picture describing Technique is considered as a good technique to be implemented in English for Business to enhance students' skill at speaking, but in this era the learning activity should be adjusted with the media of technology that is relevant to the material of learning itself. One of media that is considered more appropriate and relevant to Picture Describing Technique is KineMaster application.

Especially when the Covid-19 pandemic is striking around the world, learning system in almost every country applies online learning. Especially in Indonesia, the government still prevents face-to-face learning, especially in urban areas and red zones. The government issued an absolute education policy that learning during the Covid-19 pandemic, all schools in the red zone must conduct online learning. Both students and teachers are currently faced with a difficult situation. Teachers in particular, they are required to be proficient in using technology related to learning.

In view of such condition, it is necessary to find alternative solutions in effective and attractive learning so that all problems and obstacles that exist either faced by students and teachers can be overcome, it is necessary to have learning media that makes it easier for students to understand learning material and encourage them to be more creative in using learning media effectively. According to the author, the most appropriate media is the KineMaster application.

Researchers chose kinemaster-based learning media because there was already previous research results that show the successful application of this learning media. The research, namely: Learning Text Report with the Kinemaster-based "Cerdig" project written by Laily Amin Fajariyah in 2018 stated that almost all students agreed that learning English with the Kinemasterbased cerdig project was fun. There is only 1 (one) student who is not sure of the answer. Feeling happy and motivated, student participation also increases and this is evidenced by some students feel actively involved. By increasing student participation in learning and having fun in class, the Kinemaster-based "cerdig" project is believed to improve students' understanding of the report text being studied. Students agree with the increase in their understanding of the information 
contained in the report text they choose. The results of interviews with three randomly selected students supported the results of this questionnaire. The three children were asked about the text that they made a digital story that could provide detailed information related to their text. Even one of the students still remembers the Latin name of the animal in their digital story. Their opinion is in accordance with the results of the daily test of KD 11.3 where students who complete improve with the use of Kinemaster-based "cerdig" projects. The average score of their learning outcomes also increased. In addition to increasing students' understanding of the report text they studied, this project is also believed by many students to be able to improve their speaking skills, especially in report texts, particularly in storytelling or speaking monologue skills, and also in aspects of pronunciation and fluency. This assumption supports the statement of Robyler \& Doering (2013: 25) that technology is able to involve students in production work. In this case, the English production is a text report in the form of a digital story.

In addition, to improve students' understanding of text and speaking skills, especially in report texts, many students believe that this project will improve their skills in information and communication technology (ICT), including downloading images, doing digital storytelling with Kinemaster, and accessing youtube and uploading videos on youtube.

This research, requires students to take an active role in participating in learning conducted by teachers through online learning. With the direction given by the teacher, namely making videos about kinds of Job and profession, then they describe them in detail, both describing them orally and in text by utilizing the features in the KineMaster application as best and as attractive as possible.

This research was conducted to describe students' views on the utilization of Kinemaster applications in Implementing Picture Describing Technique of English for Tourism In Englsih Department of STKIP La Tansa Mashiro.

By carrying out this research, it's hoped, it can generate some contributions to the improvement of teaching English for Tourism as English Specific Purpose (ESP). Hopefully it can enrich the theory of teaching English for Tourism and provide practical input for English lecturers in developing teaching materials. Thus, the results of this research will be very beneficial to utilize media of learning which is more relevant and meaningful for students.

\section{A. Perception}


Perception is a word that is closely related to human psychology, has been defined in various ways, from the point of view of the layman, perception is defined as the conscious act of one's environment through physical sensations, which shows the individual's ability to understand. Meanwhile, according to expert opinion, "perception is defined in accordance with the opinions and views of a person" (Unumeri, 2009: 18).

The term perception has many perceptual frameworks or definitions expressed by experts, among others. Jarvis (2015: 108) stated that putting in and analyzing information is called perception. Another definition put forward by Blake \& Secular (2006: 1) said "perception puts us in contact with the world we live in, it shapes our knowledge of that world", they also say that what is important about perception is because it "provides people with a useful view of the world, where useful means being able to interact and effectively within our environment".

So, from the descriptions of the experts above, it can be shown that students' perceptions are students' interpretations of their experiences then shape student knowledge and provide students with useful world views.

Perception is a word that is closely related to human psychology, has been defined in various ways, from the point of view of the layman, perception is defined as the conscious act of one's environment through physical sensations, which shows the individual's ability to understand. Meanwhile, according to the opinion of experts, "Perception is defined in accordance with the opinions and views of a person" (Unumeri, 2009: 18), however, "Perception is important because it affects information in working memory. Schematic background knowledge influences perception and subsequent learning

". In fact, the research findings agree with this claim that background knowledge resulting from experience greatly influences perception. Meanwhile, experts reinforce the definition of perception as a process by which we try to understand others. Trying to get information about the temporary causes of other people's behavior (Adediwura and Tayo, 2007: 166-167).

According to Walgito (2003: 54-55), the perception is influenced by factors that have been classified, among others:

1. External factors, namely the stimulus and traits that stand out in the neighborhood behind the objects that constitute a determination or unity subtle, among others: social and environmental.. 2. Internal factors, i.e. factors related to the ability of self that comes from a relationship with facets, mental, intelligence, and bodily. 
From the various perceptual limitations above, it can be concluded that perception is a mental process in an individual in their effort to recognize something which includes the activity of processing a stimulus that is captured by the senses of an object, so that an understanding of the stimulus is obtained. Perception is the dynamic that occurs in an individual when they receive stimuli from their environment. In carrying out this interpretation there are past experiences and value systems they have. The value system here can be interpreted as the individual's judgment in perceiving an object that is perceived, whether the stimulus will be accepted or rejected. If the stimulus is interesting or there is a correspondence it will be perceived positively, and vice versa, in addition to that there is direct experience between individuals with objects perceived by individuals, both positive and negative.

Furthermore, regarding to students' perceptions about viewing the utilization of Kinemaster applications in implementing Picture Describing Technique of English for Business lessons will effect students learning process especially in this pandemic situation. If students have a positive or good perception of the subject, then students will have a good or positive motivation to learn, so the learning process will also be good, and vice versa.

\section{B. Kinemaster}

Kinemaster is a mobile application specifically designed to assist Android and iOS users modify videos from ordinary videos to more interesting and videos in order to attract the viewers to watch.. KineMaster itself was launched by a large company which is called NexStreaming, headquartered in Seoul, Korea and it has several branches around the world, such as in the United States, Spain, China and Taiwan (Adnyana et al., 2020).

\section{Interface}

The developers of kinemaster seem to have a various perspective in terms of interfaces. Therefore, developers like to focus on powerful tools and features instead of spending energy on designing interfaces that are not the main elements.

So don't be surprised if you first run the KineMaster Application you only find a very simple display of four buttons with a background in the form of a large image that looks dominating. 


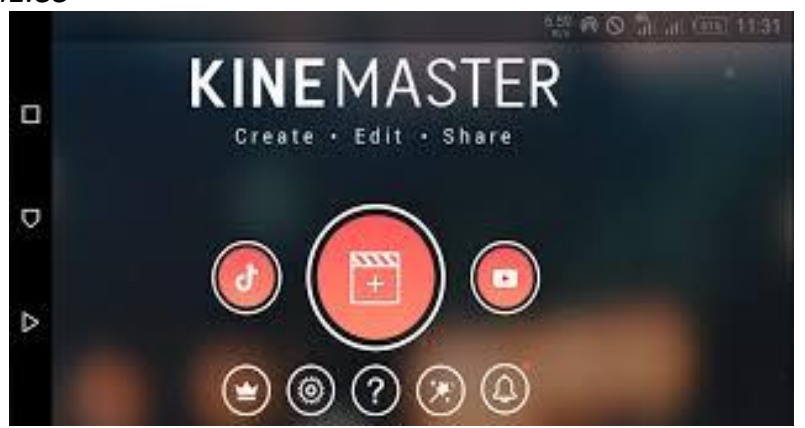

Picure 1. Kinemaster Dsiplay

Round red button is the main entrance to find the true "beauty" of kinemaster. This button will take you to the creation of a new project which will display all the video editting tools you need. The other bottons consist of settings, help, shop button, etc.

Thus the last menu contains various compelementary elements, such a audio, which can later be downloaded as a complement to the project that are being made. One more thing, when KineMaster runs for the first time, you will immediatley be put in landscape mode, including when you open the settings panel (Winarso, 2018).

\section{KineMaster Features}

- Project Assistant

When you first create a project, KineMaster will offer two types of projects, the first is Project Assistant and the second is Empty Project. Both are both together to create new video editing projects, the difference is that Project Assistant offers assistance with a series of systematic video creation processes making it much easier for new users. In Project Assistant, KineMaster will guide us from selecting videos, themes, inserting videos, filters, text and so on until it becomes a beautiful final video (Fajariyah, 2018).

- Multiple Media Support

Although it doesn't support all types of videos, KineMaster has so far been able to accommodate most of the videos recorded by smartphones. Media input in KineMaster is also fairly easy, even though you can't choose a media source, whether from internal or external memory. All media will be displayed in the same window, but separated by folder and three extra folders including Background, Favorite and Cloud Storage. The rest are folders in the device memory.(Feinberg et al., 2016a) 
- Theme

This feature also helps new KineMaster users, where there are four theme choices, including Basic, On-Stage, Serene and Travel.

- Text

Next, KineMaster also offers an option to add text into the video. Text options include an opening and an ending, where each text can be further adjusted by selecting a color and also the type of text that suits the user's taste.(Feinberg et al., 2016b).

- Audio

It's incomplete if a video editing application like KineMaster doesn't have a background sound feature. To differentiate themselves from other applications, KineMaster has a wider range of options, where users can choose the source they feel is most appropriate for them. For example, there is a Music Assets option from the store, then SFX Assets, recordings, songs from device memory, albums, artists and even genres and additional menu folders if the user has a reference from their local device. In addition to offering more complete audio source options, KineMaster also allows users to set how loud the background sound is, how the video first appears and ends, then the viewing duration for photo content types.(Adnyana et al., 2020).

\section{- $\quad$ Complete Editing Tool}

Now, take a look at the winning features. In this section, the true abilities of the KineMaster will be revealed. When the video has been inputted, the audio has also been selected and the text has been typed, all the pieces will be gathered together in the main editing window. In this window, there's an awful lot going on. The first time I was in this window, it took me about 30 minutes to understand how it works and what each button does (Indriani \& Pangaribuan, 2020). 


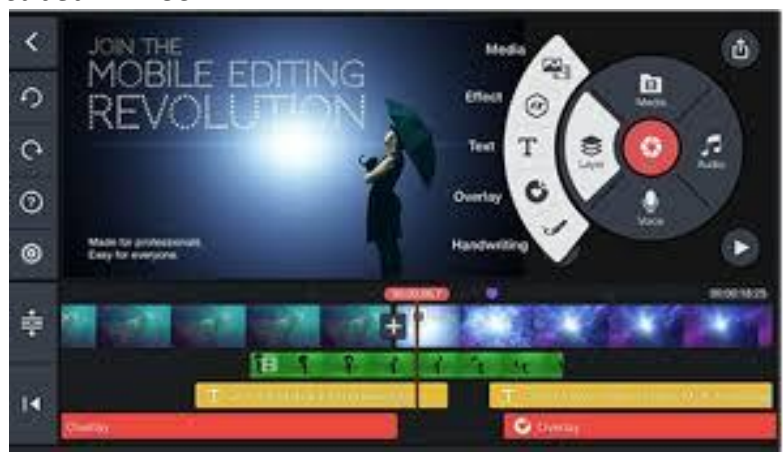

Picture 7. Complete Editing Tool

Furthermore, there are several features that are found. To make it easier, this will only create a complete list with terms it can understand. The original language may be different.

1. Multiple layer support

2. Voice over

3. Playback

4. Sharing

5. Cut, Copy, Crop

6. Color filters

7. Color adjustment

8. Vignette

9. Trimming

10. Split

11. Rotate

12. Records from cameras and cancorders

13. Drag amd Drop

14. Capture frame

15. Duplicate

16. Undo / Redo

For those ones who tend to judge things from the first sight will probably be difficult to find KineMaster to like KineMaster in the early minutes. This is my first time using KineMaster to feel a stiff impression. However, that impression faded when entering the main editing window. So, if you are allowed to provide input, it would be awful if the KineMaster developer did a makeover 
on the side of the interface. How do you make the main interface look pretty and not clunky. Performance also makes me compatible with KineMaster.

\section{Sparks}

- Small file size

- Smooth performance

- Very complete features

- The Project Assistant feature is very helpful for new users

\section{Slacks}

- The interface seems stiff

- Difficulty changing text size

- A single media source makes it difficult to select the video file

- There is no back button in the Project Assistant type, causing doubts when you want to return to the previous process.

\section{English for Tourism}

Indonesia is a large archipelagic country that has many exotic beaches and various kinds of arts and culture. This makes Indonesia has very promising tourism prospects. Of the many tourism areas in Indonesia, Banten can be said as an area that has many tourism sectors that are being developed and some are already quite popular. For example; Anyer Beach and Tanjung Lesung Beach which are visited by many tourists come from abroad for a vacation and enjoy the exoticism of the beaches. As is known, foreign languages play a vital role in the tourism industry. Tourism management without the support of foreign language skills and proficiency will hinder the smoothness of providing services to tourists who incidentally come from various parts of the world.

For this reason, having foreign language skills, especially English as an international language, is absolutely necessary for Banten tourism actors. Tourism English is classified into English for Specific Purposes (ESP) or English for certain purposes in this case for tourism purposes or English for Tourism. Similar to other sectors, English for Tourism has its own important terms and vocabulary. For those ones who are interested in working in the field of 
tourism or tourism/hospitality, they can deepen their English skills by taking English courses available in Banten area. In this case, STKIP La Tansa Mashiro has been trying to find the appropriate solution by adding the subject of English for Tourism implemented at English Department. It can improve students' knowledge in English for Specific Purposes (ESP). It can be related to any kind of fields of interest such as English for front office, guest relations, housekeeping, bell boy, receptionist and others.

According to Leslie \& Russell (2006), being skillful in foreign language skills is necessary for people working in the tourism and hospitality sector. The reason is that it is the means for having communication with foreign tourists and understanding cultural differences. In fact, for those who are seeking employment in the tourism, hospitality and service industry, it is essential to stay highly motivated in order to be accurately fluent in a high level of professional service language. In fact, they are required to become proficient in English for Tourism Purposes (Cravotta, 1990). Moreover, Cho (2005) believes that English for tourism is viewed as an area of business English and incorporate business English and English for academic purposes by bridging workplace communication and classroom use. This can help to increase the job opportunities in the international industry.

English for tourism is known as one of the attractive subjects since many of the people will be a tourist at least once in their lifetime. Moreover, learning English for tourism purposes is crucial for those who are working in guest-host relation section such as hotels, travel agencies, restaurants, information centres and tourist attractions. In industrial sectors, English has recently become a core subject, and hospitality training programs help the employees achieve English proficiency to fulfil the job responsibilities (Hsu, 2010; Chen, Chiu, \& Lin, 2011; Kuppan, 2008).

\section{METHOD}

This research was conducted using a survey. The target population of this study were all students who were actively and enthusiastic in joining the English for Tourism class at English Department of STKIP La Tansa Mashiro.

The sample in this study was part or representative of the population studied, (Arikunto, 2002: 109). Determination of the sample used in this study uses a type of random sampling method. In this study, data collection was done by filling out a questionnaire. Questionnaire is a technique of collecting data through forms that contain questions raised in writing to a person or 
Prosiding The 1st National Conference on Applied Business, Education, \& Technology (NCABET)"

Unversitas Bina Bangsa 2021

DOI Article : $10.46306 /$ ncabet.v1i1.35

group of people to get answers or responses and information needed by researchers (Mardalis: 2008: 66).

\section{RESULT AND DISCUSSION}

The number of students who were respondents in this study were 165 students from 6 classes. From the total respondents, 80 percent or 132 students agree that the presentation of the lecturer in explaining the procedure of Picture Describing Technique using KineMaster is quite interesting and easy to understand, meanwhile 20 percent or 33 students stated strongly agree.

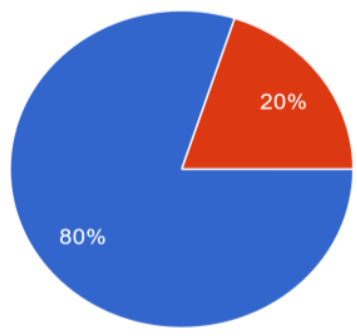

Chart 1. The Statement of Clarity of Teacher's Presentation

Furthermore, 112 students or around 67,9 percent of students stated that they agree that Describing Picture Technique using KineMaster application is particularly appropriate and helpful to train and improve students' speaking skills. Meanwhile, 45 students or 27,3 responded strongly agree, but the remaining 8 students or 4,8 percent of students stated disagree that English learning using KineMaster application is appropriate to train students at speaking skills.

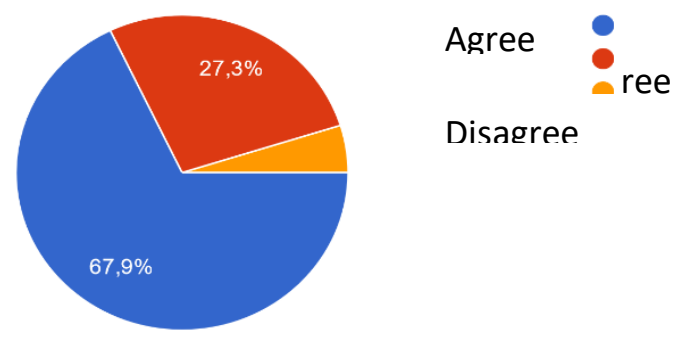

Chart 2. Describing Picture Technique using KineMaster is helpful to Improve Students' Speaking Skills

Meanwhile, the students who agree that learning media using KineMaster application is easy to use, interesting, suitable and appropriate to be implemented in English for Toursim subject is about 128 students or 78,2 percent, and 15,8 percent or 26 students stated strongly agree and 
Prosiding The 1st National Conference on Applied Business, Education, \& Technology (NCABET)"

Unversitas Bina Bangsa 2021

DOI Article : 10.46306/ncabet.v1i1.35

unfortunately 10 students or around 6,1 percent of students stated disagree and they consider that KineMaster is not suitable to be Implemented in English for Business subject.

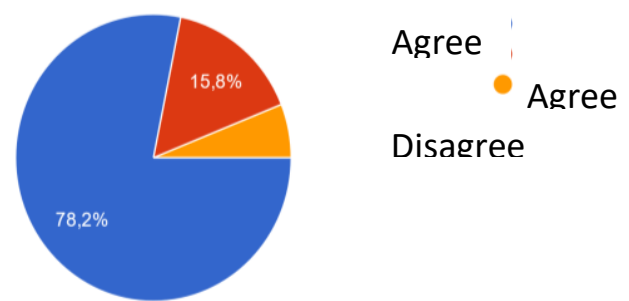

Chart 3. KineMaster is suitable to be implemented in English for Business

Furthermore, students' responses to the statement that KineMaster application is very suitable and relevant to enhance productive skills in English, were responded by 137 students or $83 \%$ agreed, 23 students or 13,9 percent stated strongly agree, and 5 students or 3\% stated disagree. From the responses obtained, the most of students still think that KineMaster application is very suitable to be used in learning English related to productive skills, especially the active students, they are very enthusiastic and excited to learn using KineMaster.

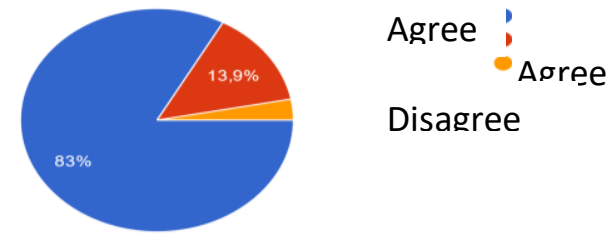

\section{Chart 4. KineMaster is Relevant to Enhance Productive Skills}

The next statement was about the Picture Describing Technique which one of the English for Tour Guide teaching techniques is the best and most relevant technique implemented through KineMaster application. Students responded, as many as 125 students or 75,8 percent of students stated agree, 33 students or 20 percent of students stated strongly agree, meanwhile few students stated disagree around 4,2 percent of students or 7 students. From these responses it can be concluded that the majority of respondents think that the Picture Describing Technique is very beneficial and relevant to be implemented through KineMaster application. 


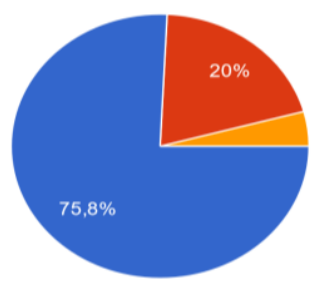

Agree

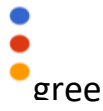

Disagree

\section{Chart 5. Teaching Describing Technique using KineMaster is the most relevant}

\section{CONCLUSION}

Various methods and media have been broadcasted and used in the teaching and learning process with the aim at motivating teachers develop creativity in teaching and can produce more meaningful learning, and it certainly will improve the quality of education. One of them is a wellknown ICT-based learning media is the KineMaster. This application is very relevant to be implemented in Picture Describing Technique for the subject of English for Tourism. KineMaster is an application that is able to create animated learning videos. The use of animation is expected to facilitate the absorption of information effectively and efficiently by students in accordance with the points above, namely the delivery of subject matter to be interesting and not boring because it contains interesting audio-visual media, videos, and colorful images (animation). In this Picture Describing Technique the students made a description about jobs and profession through video by utilizing the features of KineMaster application, so their performance in describing picture become more interesting and eye-catching.

There are some points highlighted about the KineMaster's functions and relevancies towards English for Tourism Subject, the first point is that Describing Picture Technique using KineMaster application is particularly appropriate and helpful to train and improve students' speaking skills. The second point is that learning media using KineMaster application is easy to use, interesting, suitable and appropriate to be implemented in English for Business subject. The third point is that KineMaster application is very suitable and relevant to enhance productive skills in English, and the last point is that Picture Describing Technique is the best and most relevant technique implemented through KineMaster application. 


\section{THANK-YOU NOTE}

Deep gratitude to the Rector of University of Bina Bangsa, Dr. H. Furtasan Ali Yusuf, SE., S.Kom., MM and also all lecturers of University of Bina Bangsa.

\section{REFERENCES}

Adediwura, A \& Tayo. Perception of Teacher Knowledge, Attitude, and Teaching Skills as Predictor of Academic Performance in Nigerian Secondary Schools. Educational Research and Review Vol. 2 (7), July, 2007. Pp: 165- 171

Adnyana, P. B., Citrawathi, D. M., Putu, N., \& Ratna, S. (2020). Efektivitas Pelatihan Pembuatan Flipped Classroom Video Dengan Smartphone dan Aplikasi Kinemaster (PROGRAM PkM). 1758-1765.

Arikunto, Suharsimi (2002). Prosedur Penelitian Suatu Pendekatan Praktik. Jakarta: Rineka Cipta. Blake, Randolph \& Robert Sekuler. (2006). Perception Fifth Edition. New York.

Chen, P. C., Chiu, W. Y., \& Lin, T. Y. (2011). A study constructing holistic English for specific purposes (ESP) curriculum model for tourism and hospitality English. Education Research Journal, 1(5), 84-93.

Cho, B. (2005).Usefulness and enjoyment of simulation activities for tourism major students. Modern English Education, 6(1), 3-17.

Cravotta, J. S. (1990). English for Tourism Purposes. A new approach in the field of English for Specific Purposes. Retrieved from http://www.espfortourism.blogspot.my/2012/05/englishfor-tourism-purposes.html

Fajariyah, L. A. (2018). Pembelajaran Teks Report Dengan Proyek “Cerdig” Berbasis KineMaster. Jurnal Didaktika Pendidikan Dasar.

Feinberg, M. A., Song, K. B., \& Lim, I. T. (2016). KineMaster: pro video editing on Android. In ACM SIGGRAPH 2016 Appy Hour (pp. 1-1).

Hsu, L. W. (2010). Learning gaming English by prospective casino dealers in Taiwan: An explorative study. Journal of Foreign Language Instruction, 4(1), 69-86. Retrieved July 31, 2012, from ProQuest database.

Indriani, E., \& Pangaribuan, T. R. (2020). Efektivitas Penggunaan Media Kinemaster Terhadap Kemampuan Menulis Teks Prosedur Siswa Kelas VII Smp Swasta Muhammadiyah 05

Jarvis, Matt. (2000). Teori-Teori Psikologi Pendekatan Modern Untuk Memahami Perilaku, Perasaan Pikiran Manusia. Translated by SPA-Teamwork. 2015. Bandung: Nusa Media.

Mardalis. (2008). Metode Penelitian Suatu Pendekatan Proposal. Jakarta: Bumi Aksara Unumeri, G.O. (2009). Perception and Conflict. Nigeria

Walgito, Bimo. (2003). Pengantar Psikologi Umum. Yogyakarta: Andi Offset (http://en.m.wikipedia.org/wiki/English speaking_world)

Winarso, B. (2018). [Review App] Bikin Video Keren di Smartphone dengan KineMaster Pro Video Editor. 22 May. 